\section{New Dopamine Receptor Stimulant Drug ${ }^{1}$}

The central effects of a new tremorgenic drug, $2(p$-nitrobenzylthio)-imidazoline $(3 \mathrm{H}) \cdot \mathrm{HCl}$ (NBTI) were studied. This compound, first synthesized by Easton et al. ${ }^{2}$, caused marked tremors in rats (Sprague-Dawley male, $160-210 \mathrm{~g}$ ) and mice (Swiss male, 22-30 g) in doses above $40 \mathrm{mg} / \mathrm{kg}$, and in doses above $60 \mathrm{mg} / \mathrm{kg}$ a majority of the animals also showed clonic convulsions. All of the anticholinergic antiparkinsonism agents (atropine sulfate, (5 mg/kg), scopolamine like $\mathrm{HBr}(5 \mathrm{mg} / \mathrm{kg})$, orphenadrine citrate $(10 \mathrm{mg} / \mathrm{kg})$ and biperiden $(10 \mathrm{mg} / \mathrm{kg}))$ failed to block the NBTI-induced tremors in mice. d-Amphetamine sulfate $(10 \mathrm{mg} / \mathrm{kg})$, L-dopa methyl ester $\cdot \mathrm{HCl}(400 \mathrm{mg} / \mathrm{kg}$ base), diphenhydramine $\cdot \mathrm{HCl}(40 \mathrm{mg} / \mathrm{kg})$ and benztropine mesylate $(20 \mathrm{mg} / \mathrm{kg})$ enhanced the excitation and lethality of NBTI (50 $\mathrm{mg} / \mathrm{kg})$.

In rats a dose even as small as $15 \mathrm{mg} / \mathrm{kg}$ of NBTI produced stereotyped movements of the head and sniffing at the sides and corners of the cage. This effect started within $3 \mathrm{~min}$, and lasted for $30 \mathrm{~min}$. Pretreatment with chlorpromazine $\cdot \mathrm{HCl}(10 \mathrm{mg} / \mathrm{kg})$, perphenazine $(115 \mathrm{mg} / \mathrm{kg})$ and haloperidol $(20 \mathrm{mg} / \mathrm{kg})$ blocked the stereotyped behavior, but not the tremors. Treatment with $p$-chlorophenylalanine methyl ester $\cdot \mathrm{HCl}(400 \mathrm{mg} / \mathrm{kg}$ base given $72 \mathrm{~h}$ before NBTI) or phenoxybenzamine $(15 \mathrm{mg} / \mathrm{kg}$ given $4 \mathrm{~h}$ before NBTI) did not modify the effects of NBTI $(50 \mathrm{mg} / \mathrm{kg}$ ). This drug was very effective in antagonizing the marked depression produced in rats by treatment with reserpine $(5 \mathrm{mg} / \mathrm{kg})$ and $\alpha$-methyltyrosine methyl ester . $\mathrm{HCl}(\alpha-\mathrm{MT})(250 \mathrm{mg} / \mathrm{kg}$ base given $20 \mathrm{~h}$ after reserpine and $4 \mathrm{~h}$ before NBTI $(30 \mathrm{mg} / \mathrm{kg})$.

The influence of NBTI $(50 \mathrm{mg} / \mathrm{kg})$ on the monoamines of whole brain of rats was studied using the single extraction procedure of FLEMING et al. ${ }^{3}$. The only significant change seen was a $55 \%$ depletion of noradrenaline (NA) seen $1 \mathrm{~h}$ after treatment. Changes in NA, dopamine (DA) and serotonin ( $5 \mathrm{HT}$ ) levels were not appreciable at 30 , 120 and 240 min after NBTI treatment. The turnover rates of brain NA and DA were estimated by the method of ANDÉN et al. ${ }^{1}$. It was found that $50 \mathrm{mg} / \mathrm{kg}$ dose of NBTI decreased the turnover rates of both DA and NA, the former being more affected.

The in vitro uptake of NA and-DA by slices of hypothalamus (NA) and caudate (DA) of rats was estimated by the method of DENGLER et al. ${ }^{5}$. When compared with the catecholamine uptake inhibitor desipramine (DMI) it was found that the NBT] concentration required for blocking the uptake of ${ }^{D L}{ }^{14} \mathrm{C}-\mathrm{NA}$ by hypothalamus slices was 0.01 times the required concentration of DMI and 200 times the DMI concentration required for blocking ${ }^{14} \mathrm{C}$-DA uptake by caudate slices.

Studies are in progress to evaluate the effects of NBTI on the in vivo uptake of catecholamines, and also its behavioral, antidepressant and antiparkinsonism effects. The latter experiments are being performed on rhesus monkeys. Dyskinesias are being produced by various methods including those which involve pharmacological depletion of brain DA and also by means of appropriate lesions of brain areas. In a preliminary experiment, one rhesus monkey (female, $5 \mathrm{~kg}$ ) was made akinetic with reserpine $(5 \mathrm{mg} / \mathrm{kg} \mathrm{i} . \mathrm{m}$.) and $\alpha$-MT $(100 \mathrm{mg} / \mathrm{kg}$ base i.m. given $24 \mathrm{~h}$ after reserpine). $4 \mathrm{~h}$ after $\alpha$-MT, the animal showed akinesia, whole-body tremor, oral dyskinesia and salivation. An intramuscular dose of $15 \mathrm{mg} / \mathrm{kg}$ of NBTI caused a remarkable effect on this animal. Within $5 \mathrm{~min}$, the animal started walking around and in $8-10 \mathrm{~min}$ showed hyperactivity lasting for $30 \mathrm{~min}$ after which the animal returned to the reserpine- $\alpha$-MT depression. During the hyperactive phase, the animal behaved as though it was under the influence of a tranquilizer and the experimenters could handle it at will. No vomiting reflex was observed. Similar experiments performed on this animal one month later showed that $40 \mathrm{mg} / \mathrm{kg}$ dose of $\mathrm{L}$-Dopa ester also antagonized the reserpine- $\alpha$-MT akinesia, but its effect was much less pronounced and with a much greater delay in onset than $15 \mathrm{mg} / \mathrm{kg}$ dose of NBTI. Also, in contrast to NBTI, the L-Dopa-treated animal was as aggressive as before any treatment.

The stereotyped behavior caused by NBTI in animals, the blockade of these effects by DA receptor blocking drugs and the decrease in the turnover rate of catecholamines are all typical of drugs which stimulate DA receptors (such as apomorphine), although an effect on $5 \mathrm{HT}$ receptors cannot be ruled out as yet. The powerful effect NBTI produced in animals pretreated with reserpine and $\alpha$-MT show that this compound could act even in the absence of DA. The absence of aggressiveness and emesis are important qualities of this drug. All these findings indicate that NBTI or agents with similar structures could be valuable in the treatment of Parkinson's disease and possibly mental depression.

Zusammentassung. Es wird der Nachweis erbracht, dass 2(p-nitrobenzylthio)-Imidazolin (3H) - HCl (NBTI) Dopamin-Rezeptoren von Mäusen, Ratten und Affen direkt zu stimulieren vermag.

\section{K. Menon ${ }^{6}$, W. G. Clark and D. Aures?}

Psychohopharmacology Research Laboratory,

Veterans Administration Hospital

Sepulveda (California 91343, USA),

Department of Biological Chemistry,

Center of Health Sciences, University of California,

Los Angeles (California, USA), and

Department of Medical Pharmacology,

University of California, Irvine (California, USA), 27 September 1971.

1 Final paper in press, Eur. J. Pharmac. (1972).

2 N. R. Easton, A. Hlynsky and H. Foster, J. Am. chem. Soc. 73 , 3507 (1951).

3 R. M. Fleming, W. G. Clark, E. D. Fenster and J. C. Towne, Analyt. Chem. 37, 692 (1965)

4 N.-E. Anden, H. Corrodi and K. Fuxe, in 'Proc. Symp. of Brit. and Scand. Pharmacol. Soc.', Edinburgh, (Ed. G. Hooper; Macmillan, New York 1968), p. 38.

5 H. J. Dengler, I. A. Michaelson, H. E. Spiegel and E. Titus, Int. J. Neuropharmac. 1, 23 (1962).

6 Fellow, Foundations Fund for Research in Psychiatry.

7 The authors wish to thank Dr. G. ULLYOT, SKF Laboratories, for gifts of NBTI and chlorpromazine; Dr. H. Corrodi, AB Hässle, Göteborg, Sweden, for the methyl ester hydrochlorides of L-Dopa, $\alpha$-methyl- $p$-tyrosine and $p$-chlorophenylalanine; McNeil Laboratories, Inc., Fort Washington, Pennsylvania, for the haloperidol; and Schering Corporation, Bloomfield, New Jersey, for perphenazine. Thanks are also due to A. SchindLer for his skillful technical assistance. 